UDC: 334.71

JEL: C19

\title{
BUSINESS ACTIVITY OF AGRICULTURAL ENTERPRISES: ANALYTICAL REVIEW
}

\section{ДІЛОВА АКТИВНІСТЬ СІЛЬСЬКО ГОСПОДАРСЬКИХ ПІДПРИЕМСТВ: АНАЛІТИЧНИЙ ОГЛЯД}

Alla A. Balan, PhD in Economics, Associate Professor Odessa National Polytechnic University, Odessa, Ukraine ORCID: 0000-0002-2017-8813

Email:allabalan@ukr.net

Vlad S. Timonyuk Odessa National Polytechnic University, Odessa, Ukraine ORCID: 0000-0003-3861-5193

Email: annatymonyuk@gmail.com

Received 03.12.2019

\begin{abstract}
Балан А.А., Тимонюк В.С. Ділова активність підприємств: аналітичний огляд. Оглядова стаття.

У статті проведено аналітичний огляд та охарактеризована ділова активність двох підприємств, України. Наведено структуру валової доданої вартості за підсумками 2018 року, виявлено найбільші сектори серед них. Проведено аналіз діяльності цих підприємств, а саме: горизонтальний та вертикальний аналіз балансу, розрахунок темпів приросту, показників рентабельності, оборотності, фінансової незалежності, наведено динаміку дебіторської заборгованості та запасів у діаграмах порівняння з групуванням за період з 2016 по 2018 роки. У статті на підставі розрахунків здійснена оцінка можливостей щодо подальшого розвитку підприємств, що досліджуються.

Ключові слова: підприсмства сільського господарства, фінансовий аналіз діяльності.
\end{abstract}

Balan A.A., Timonyuk V.S. Business activity of enterprises: analytical review. Review article.

The article deals with the analytical review and describes the business activity of two enterprises, Ukraine. The structure of gross value added in 2018 is given, the largest sectors among them are identified. The analysis of these enterprises activities is carried out, namely: horizontal and vertical analysis of the balance sheet, increment rate calculation, profitability ratio, turnover ratio, financial independence, the dynamics of debts receivable and margins in the comparison charts with the grouping for the period from 2016 to 2018 are given. On the basis of calculations of possibilities assessment concerning the investigated enterprises further development is carried out in the article.

Keywords: agricultural enterprises, financial analysis

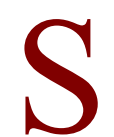

tudies of the dynamics and intensity of economic development, the expansion rate of an enterprise activity are closely related to the concept of "business activity". Business activity research is one of the important areas of the financial condition analysis of the enterprise, which allows not only to adapt to changes in the market, but also to actively respond and influence it. Carrying out such analysis allows to analyze economic dynamics of general indicators of enterprises economical activities, to estimate and forecast admissible and economically feasible rates of indicators growth.

Analytical review of business activity of a number of Ukraine's enterprises for the period from 2016 to 2018 is relevant in terms of obtaining general information about the enterprises financial condition, their ability to survive and develop.

\section{Analysis of recent researches and publications}

Many researches of scientific and educational nature are devoted to the issues of financial analysis of enterprises activity, in particular Azarova A.O., Ruzakova O.V. [1], Voloshchuk L.O. [2], Bezborodova T.V. [3], Kolomiiets N.O., Pavlichenko V.M.[4], Kramarenko H.O. [5], Savytska H.V. (Savutska, H.V., 2018) [6] and other scientists. The analysis results can be found in separate publications on research results [7], in official issues of the State Statistics Service of Ukraine [10], etc. Burachek I.V., Mykhailenko N.V [11], Lupenko Yu.O., MeselVeseliaka V.Ya [12].

The aim of the article is to present the analytical review results of business activity of Ukraine's agricultural enterprises for the period from 2016 to 2018, the assessment of their opportunities for further development. 


\section{The main part}

The agricultural sector of Ukraine is one of the leading branches of Ukraine's economy. According to the State Statistics Service, in 2018 the highest growth in the gross product volume was recorded in financial and insurance activities $(+12.4 \%)$, in agricultural sector $(+7.8 \%)$, in construction $(+7.2 \%)$, and also in the area of IT and telecommunications $(+6 \%)$.
"Negative development" was recorded in the field of health care $(-1.7 \%)$ and education $(-1.1 \%)$.

The largest share in Ukraine's GDP was accounted for by such industries as wholesale and retail trade (471 billion $\mathrm{UAH}$ ), processing industry (409 billion UAH), agricultural sector (360 billion $\mathrm{UAH}$ ) and mining industry (213 billion UAH).

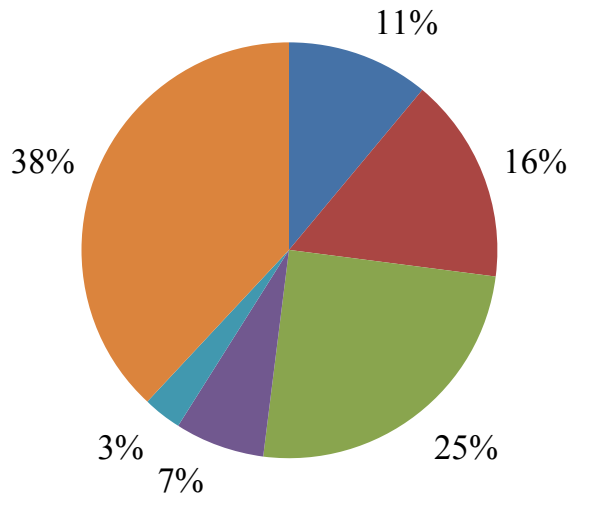

Agricultural sector

- Trade

Industry

- Transport

- Construction

athers

Figure 1. The Structure of Gross Value Added of Ukrainian Industry according to the Results of 2018. Source: compiled by the authors on materials [8]

The data of two agricultural enterprises were used in the study. Characteristics of the enterprises are given in the table 1 and the table 2 .

The balance sheet currency grows in enterprises A and $\mathrm{B}$ throughout the study period (by $39.02 \% ; 7.11 \%$ and $18.48 \% ; 14.10 \%$, respectively), which indicates the expansion of enterprises economic activity. At the enterprise A, $20.07 \%$ increase in net operating income was observed in 2017, and a decrease of $10.29 \%$ in 2018. At the enterprise $B$, the decrease in net operating income by $9.62 \%$ occurred in 2017 , and the increase by $79.64 \%$ was in 2018 .

Table 1. Characteristics of the Enterprises under Consideration

\begin{tabular}{|c|c|c|}
\hline \multirow{2}{*}{$\begin{array}{l}\text { Characteristics of research } \\
\text { objects }\end{array}$} & \multicolumn{2}{|c|}{ The enterprise } \\
\hline & $\mathrm{A}$ & $\mathrm{B}$ \\
\hline Legal corporate form & PAE & LLC \\
\hline Term of continuous activity & 20 years & 18 years \\
\hline Location & Odessa & Odessa \\
\hline $\begin{array}{l}\text { Type of activity according } \\
\text { to UICS } \\
\text { (Ukrainian Industry } \\
\text { Classification System) }\end{array}$ & $\begin{array}{c}\text { - 01,41. Cattle breeding } \\
-01.46 \text {. pig breeding } \\
-0.1 .61 \text { provision of services in crop } \\
\text { production } \\
-46,04 \text {. grain trade } \\
-46.21 . \text { trade in seeds and animal feed } \\
\text { - 01.11. cultivation of grain and industrial } \\
\text { crops }\end{array}$ & $\begin{array}{l}\text { 01.11. cultivation of grain and } \\
\text { industrial crops }\end{array}$ \\
\hline Source of information & $\begin{array}{l}\text { Financial reporting of the enterprise } \\
\text { (simplified forms 1-st, 2-d) }\end{array}$ & $\begin{array}{l}\text { Financial reporting of the } \\
\text { enterprise (simplified forms 1- } \\
\text { st, 2-d) }\end{array}$ \\
\hline $\begin{array}{l}\text { The amount of employees } \\
\text { (average), people }\end{array}$ & $\begin{array}{c}2016 \text { - } 6 \text { people , } 2017 \text { - } 5 \text { people, } 2018 \text { - } \\
\text { people }\end{array}$ & $\begin{array}{c}2016-4 \text { people, } 2017-4 \\
\text { people } \\
2018-3 \text { people }\end{array}$ \\
\hline
\end{tabular}

Source: compiled by the authors on materials [9] 
Table 2. Horizontal Analysis of the Balance Sheet Currency and ths Financial Performance Report

\begin{tabular}{|c|c|c|c|c|c|c|}
\hline \multirow{2}{*}{ Indicator } & \multicolumn{3}{|c|}{ The enterprise $\mathrm{A}$} & \multicolumn{3}{|c|}{ The enterprise $\mathrm{B}$} \\
\hline & 2016 & 2017 & 2018 & 2016 & 2017 & 2018 \\
\hline $\begin{array}{l}\text { The value of the } \\
\text { enterprise } \\
\text { (currency } \\
\text { balance), } \\
\text { thousand UAH }\end{array}$ & 4516.8 & 6279.4 & 6726 & 39.5 & 46.8 & 53.4 \\
\hline Increment rate, $\%$ & & 39.02 & 7,11 & - & 18.48 & 14.10 \\
\hline $\begin{array}{l}\text { Gross profit, } \\
\text { thousand UAH }\end{array}$ & 6960 & 8357 & 7497 & 9525 & 8609 & 15465 \\
\hline Increment rate $\%$ & - & 20.07 & -10.29 & - & -9.62 & 79.64 \\
\hline $\begin{array}{l}\text { Other operating incomes, } \\
\text { thousand UAH }\end{array}$ & - & 200 & - & - & 55 & - \\
\hline Increment rate, $\%$ & & 100 & - & - & -45 & - \\
\hline $\begin{array}{l}\text { Other incomes, } \\
\text { thousand UAH }\end{array}$ & - & - & - & - & 35 & - \\
\hline Increment rate, $\%$ & - & - & - & - & 100 & - \\
\hline \multicolumn{7}{|l|}{ Cost value, } \\
\hline thousand UAH & 5460 & 7315 & 6709 & 6035 & 319 & 11402 \\
\hline Increment rate, $\%$ & & 33.97 & -8.28 & - & -94.71 & 3474.29 \\
\hline $\begin{array}{l}\text { Gross profit, thousand } \\
\text { UAH }\end{array}$ & 1500 & 1042 & 788 & 3516 & 2574 & 4063 \\
\hline Increment rate, $\%$ & - & $-30,53$ & -24.38 & - & -26.79 & 57.85 \\
\hline $\begin{array}{l}\text { Other operating expenses, } \\
\text { thousand UAH }\end{array}$ & 202 & 657 & 765.2 & 8283 & 2369 & 3109 \\
\hline Increment rate, $\%$ & - & 225,25 & 16.47 & - & -71.40 & 31.24 \\
\hline $\begin{array}{l}\text { Other expenses, thousand } \\
\text { UAH }\end{array}$ & 150 & - & - & - & - & 354 \\
\hline Increment rate, $\%$ & - & 57.33 & 36.44 & - & 100 & 43.90 \\
\hline Net income & & & & & & \\
\hline $\begin{array}{l}\text { (loss), } \\
\text { thousand UAH }\end{array}$ & 1532.5 & 2880.5 & 3029.0 & 1013 & 3007.0 & 3607.0 \\
\hline
\end{tabular}

Source: compiled by the authors on the basis of materials [9]

From these calculations it is possible to conclude that net income in the reporting year compared to the base increased by 148.5 thousand UAH $(5.16 \%)$ for the enterprise A and 600 thousand UAH (19.95\%) for the enterprise $\mathrm{B}$.

In the enterprise B (in 2018) the growth rate of sales revenue exceeded the growth rate of the balance sheet currency, which indicated an increase in economic potential of revenue, increased resource efficiency (increase in income from each hryvnia invested in the enterprise property value), which was in contrast to the enterprise A (decrease by $10.29 \%$ in 2018). The increment rate of gross profit was for the enterprise A (24.38\%) in 2018 and in 2017 for the enterprise B $(26.79 \%)$. After the decline of this indicator in the enterprise $\mathrm{B}$, it grew in 2018. The enterprise A suffered a loss in 2017-2018, and the enterprise B in 2017. This analysis shows the need to find ways to reduce costs and increase the enterprises revenues to achieve efficiency.
In order to analyze the situation, a vertical and horizontal analysis of their financial reporting was performed.

Vertical analysis means the data presentation on the enterprise economic activity in the form of relative indicators due to the share of each article in the overall result and their changes assessment in the dynamics.

Data on the vertical analysis of enterprises financial reporting are given in the table 3.

During the study period, the tendency to reduce the share of fixed assets at the end of the period was observed. The largest share of enterprise assets was concentrated in fixed assets, namely property assets, which indicated their heavy structure, and therefore not high level of liquidity and financial stability of the enterprise, the result of heavy asset structure was significant overhead costs and high sensitivity to revenue changes. At the enterprise $\mathrm{A}$, current assets predominated over fixed ones, which indicated an increase in liquidity in the coming years. 
Table 3. Vertical Balance Analysis

\begin{tabular}{|l|c|c|c|c|c|c|c|c|c|c|c|c|}
\hline & \multicolumn{5}{|c|}{ The enterprise A } & \multicolumn{5}{c|}{ The enterprise B } \\
\cline { 2 - 14 } & \multicolumn{2}{|c|}{2016} & \multicolumn{2}{|c|}{2017} & \multicolumn{2}{|c|}{2018} & \multicolumn{2}{c|}{2016} & \multicolumn{2}{c|}{2017} & \multicolumn{2}{c|}{2018} \\
\cline { 2 - 13 } & $\begin{array}{l}\text { Indicato } \\
\text { and, } \\
\text { UAH }\end{array}$ & $\%$ & $\begin{array}{c}\text { Thous } \\
\text { and, } \\
\text { UAH }\end{array}$ & $\%$ & $\begin{array}{c}\text { Thous } \\
\text { and }\end{array}$ & $\%$ & $\begin{array}{c}\text { Thous } \\
\text { and, } \\
\text { UAH }\end{array}$ & $\%$ & $\begin{array}{c}\text { Thoud } \\
\text { and, } \\
\text { UAH }\end{array}$ & $\%$ & $\begin{array}{c}\text { Thous } \\
\text { and, } \\
\text { UAH }\end{array}$ & $\%$ \\
\hline $\begin{array}{l}\text { Fixed } \\
\text { assets }\end{array}$ & 1522.3 & 33.7 & 2472.8 & 43.4 & 2768.8 & 42.2 & 723 & 46.9 & 5753 & 49.3 & 4899 & 19.4 \\
\hline $\begin{array}{l}\text { Current } \\
\text { assets }\end{array}$ & 2995.5 & 66.3 & 3806.3 & 62.6 & 3956.7 & 59.1 & 819 & 53.2 & 5919 & 50.7 & 20309 & 80.6 \\
\hline Equity & 3815.4 & 84.5 & 5163.4 & 83.2 & 5311.9 & 81 & 1015 & 65.3 & 9659 & 82.8 & 10259 & 40.7 \\
\hline $\begin{array}{l}\text { Current } \\
\text { liabilities }\end{array}$ & 700.4 & 15.5 & 557.7 & 9.9 & 985.6 & 17.7 & 527 & 34 & 2007 & 17.2 & 14949 & 59.3 \\
\hline
\end{tabular}

Source: compiled by the authors on the basis of materials [9]

In 2018 the enterprise B had a small share of fixed assets, that indicated the formation of a sufficiently mobile structure of assets, which accelerated the enterprise turnover.

At the enterprise A the depreciation of property assets was 152.00 thousand UAH, 193.00 thousand $\mathrm{UAH}$; at the enterprise B was 2199.00 thousand UAH, 3901.00 thousand UAH, which was a negative trend. As of 2018, fixed assets of the enterprises comprised $42.2 \%$; $19.4 \%$ respectively. Current assets accounted for the remaining $59.1 \%$; $80.6 \%$ respectively.

At the end of 2016, the equity base in financial resources for enterprise A was $84.5 \%$, and in 2017 $83.2 \%$, and in $2018-81 \%$, for the enterprise $\mathrm{B}$, this figure decreased in 2018 to $40.7 \%$ compared to 2017
$82.8 \%$. This situation was negative for the enterprises.

Retained loss amounted to $33.9 \% ; 45.9 \% ; 45.0 \%$ - for the enterprise A, and for the enterprise B $65.7 \%, 25.8 \%, 14.3 \%$, respectively, for 2016 - 2018. Added capital for the enterprises A and B was absent for 2016, and for $2017-2018$ it consituted $57.0 \%$, $26.4 \%$, and $08 \%, 21.8 \%$, respectively. Other current liabilities of the enterprise A amounted to $15.5 \%$; $9.9 \% ; 17.7 \%$ and $34 \%, 17.2 \%, 59.3 \%$ for the enterprise B.

Horizontal balance analysis is a comparison of each balance sheet item and the calculation of changes in absolute and relative values, as well as the qualitative characteristics of the detected deviations. Data on the horizontal analysis of financial reporting are given in the table 4 .

Table 4. The Horizontal Analysis (Absolute and Relative Deviation)

\begin{tabular}{|c|c|c|c|c|c|c|c|c|}
\hline & \multicolumn{4}{|c|}{ The enterprise A } & \multicolumn{4}{c|}{ The enterprise B } \\
\hline Indicator & \multicolumn{2}{|c|}{$2017-2016$} & \multicolumn{2}{|c|}{$2018-2017$} & \multicolumn{2}{|c|}{$2017-2016$} & \multicolumn{2}{|c|}{$2018-2017$} \\
\hline & $\begin{array}{c}\text { Thousand, } \\
\text { UAH }\end{array}$ & $\%$ & $\begin{array}{c}\text { Thousand, } \\
\text { UAH. }\end{array}$ & $\%$ & $\begin{array}{c}\text { Thousand, } \\
\text { UAH. }\end{array}$ & $\%$ & $\begin{array}{c}\text { Thousan } \\
\text { d, } \\
\text { UAH }\end{array}$ & $\%$ \\
\hline Fixed assets & 950.5 & 162.44 & 296 & $\begin{array}{c}111.9 \\
7\end{array}$ & 503.0 & 795.71 & -854 & 85.16 \\
\hline Current assets & -670.2 & 77.61 & 150.4 & $\begin{array}{c}103.9 \\
5\end{array}$ & 504.4 & 721.98 & 3882.1 & 34.35 \\
\hline Equity & 148.5 & 102.88 & -1348 & 73.89 & 864.4 & 951.63 & 600 & 106.21 \\
\hline $\begin{array}{c}\text { Current } \\
\text { liabilities }\end{array}$ & 428 & 176.84 & -285.2 & 71.06 & 148.0 & 380.83 & 12942 & 744.84 \\
\hline
\end{tabular}

Source: compiled by the authors on the basis of materials [9]

Compared to previous years, the enterprises assets are growing. this indicates an increase in the enterprises potential to generate profits, as the amount of assets involved in the production, investment and financial process is growing.

At the beginning of the study period, in 2016 the amount of debts receivable for goods, works and services consisted of 27.3 thousand UAH, and 482.0 thousand UAH respectively at the enterprises A and B. In subsequent years, this indicator increased at the enterprises, which negatively influenced the financial costs, because it was necessary to attract additional funds.

There was a decrease in inventories at the enterprise A, which negatively affected the enterprise development. The opposite situation was observed at 
the enterprise B - the increase in inventories, which contributed to the enterprise further development. The high share of debts receivable in the assets of the balance sheet affected the stability of the enterprises financial condition. The enterprises had an active outsranding balance (total debts receivable exceeded accounts payable), which indicated that the enterprises provided their customers with free commercial loans in excess of funds received in the form of deferred payments to commercial creditors or calculation with postpayments.

Registered capital and additional capital remained unchanged at enterprises $\mathrm{A}$ and $\mathrm{B}$ during the study period. The enterprises $\mathrm{A}$ and $\mathrm{B}$ had additional capital. All the enterprises did not form reserves for future expenses and payments. The amount of deferred income remained stable because the enterprises did not dispose of deferred income during the study period. Long-term liabilities of the enterprise A were present in 2018, they were absent at the enterprise B throughout the study period. The amount of short-term liabilities of the enterprises A, B at the end of the study period increased, which negatively affected the enterprises liquidity. In 2016, the value of all liability sides amounted to 4.515.0 thousand UAH and 1542.0 thousand UAH at the enterprises $A$ and $B$, respectively. At the end of the study period, this indicator amounted to 6272.5 thousand UAH. and 25208 thousand UAH, which affirms an increase in enterprises financial resources.

The figure 2 shows the dynamics of the number of inventories for 3 years for the enterprises $\mathrm{A}$ and $\mathrm{B}$. For the enterprise $\mathrm{A}$, the number of inventories increased during 2016-2017, and decreased in 2018, which in absolute terms is 925.0 thousand UAH and 348.0 thousand UAH and in relative terms growth rate of $135.3 \%$ and $90.2 \%$; increment rate of $35.3 \%$ and $9.8 \%$.

At the enterprise $\mathrm{B}$ inventories increased in 2016-2018, which in absolute terms was 4388.0 thd $\mathrm{UAH}$ and 7038.0 thousand $\mathrm{UAH}$ and in relative terms growth rate of $1820.4 \%$ and $236.1 \%$; increment rate of $1720.4 \%$ and $136.1 \%$.

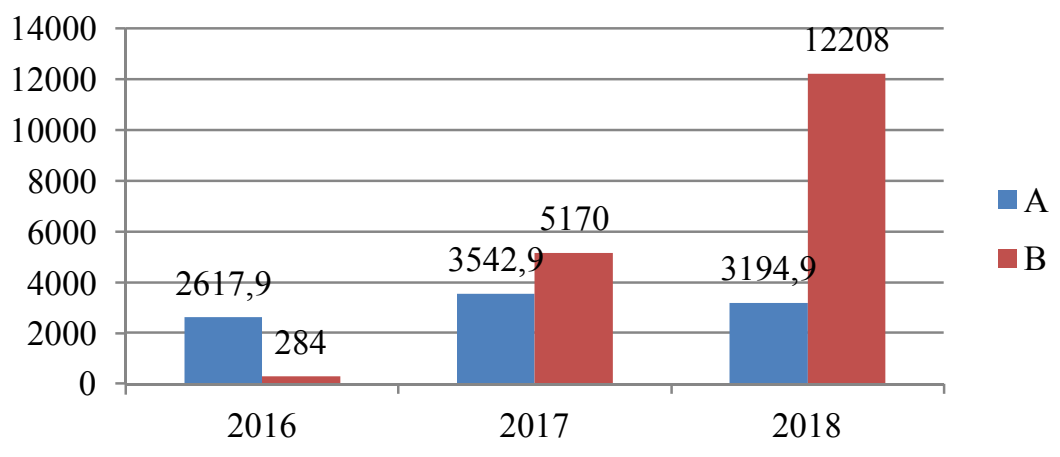

Fig. 2. Inventories comparison chart, thd. UAH Source: the authors' own development

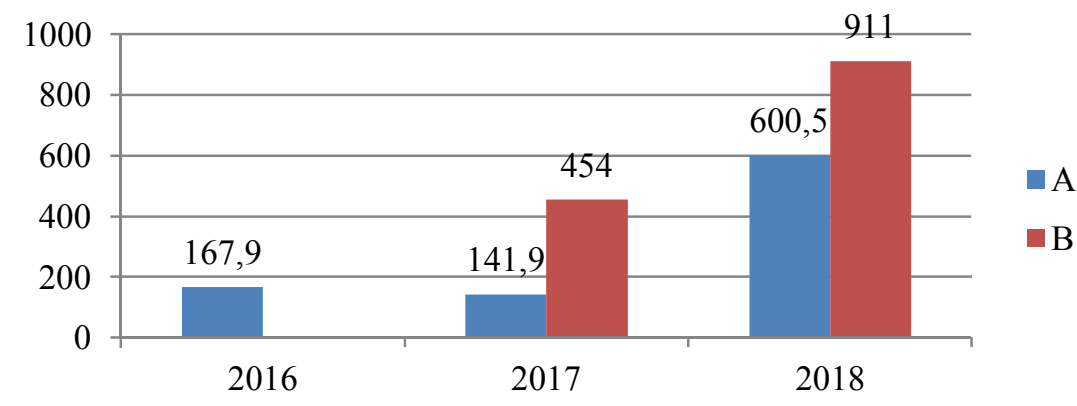

Fig. 3. The debts receivable dynamics, thd. UAH Source: the authors' own development

In 2016, debts receivable for the enterprise $\mathrm{A}$ amounted to 167.9 thd. UAH, for the enterprise the B it was absent for this period. In 2017-2018, its volume increased by enterprises. The absolute deviation on the enterprise $\mathrm{A}$ was 26,9 thousand $\mathrm{UAH}$. and 3,650 thousand UAH, for the enterprise B was 457 thousand UAH. (increased due to the emergence of buyers' new debts). The growth rate of debts receivable for the enterprise A was $84.97 \%$ and $2688.65 \%$, for enterprise B was $200.67 \%$ at the end of the period. The increment rate for the enterprise A was $16.02 \%$ and $2588.65 \%$, for the enterprise B was 100.66. at the end of the period.

Characteristics of the enterprises' position for 3 years are given in the tables - 5, 6, 7 . 
Table 5. Profitability Ratios

\begin{tabular}{|c|c|c|c|c|c|c|}
\hline \multirow{2}{*}{ Profitability } & \multicolumn{3}{|c|}{ The enterprise A } & \multicolumn{3}{c|}{ The enterprise B } \\
\cline { 2 - 7 } & 2016 & 2017 & 2018 & 2016 & 2017 & 2018 \\
\hline - output sold, \% & $-24,69$ & 2,03 & 9,69 & 3,18 & 3,25 & 4,32 \\
\hline - total assets, \% & 3,22 & 2,75 & 2,28 & 1,60 & 2,28 & 2,66 \\
\hline- equity, \% & 2,574 & 1,88 & 8,23 & 12,02 & 3,25 & 4,94 \\
\hline production, \% & $-10,2$ & 2,07 & 9,82 & 3,18 & 3,23 & 4,85 \\
\hline
\end{tabular}

Source: compiled by the authors on materials [9]

Sales margins characterize the probability of production sold by the enterprise. This indicator is determined by the ratio of difference in the volume of output sold at sales prices and the cost of goods sold to the cost of goods sold. There was a decrease in the indicator for the enterprise A in 2016 and its increase was in 2017 - 2018 by $7.66 \%$. The enterprise B had a steady growth trend, as in 2016 the indicator was $3.18 \%$, in 2017 it increased to $3.25 \%$, in 2018 it was $4.32 \%$ ). There was an increase of $1.14 \%$ during the study period.

Return on total assets shows the effictive use of all available assets of the enterprise (The enterprise A had an inefficient use over the whole period, the enterprise B was efficient).

Return on equity is a financial ratio that characterizes the efficiency of using the equity. It shows the return (rate of return) on invested equity. Maximizing this indicator is an important task that must be performed by enterprise managers. It increased by $6.35 \%$ for the enterprise $\mathrm{A}$ in 2018 compared to 2017 , for the enterprise B by $1.69 \%$. This means that the assets worked efficiently, which lead to making a profit.

Production profitability is a concept that characterizes the economic efficiency of production, in which the enterprise on account of proceeds in cash from the products sale (works, services) fully reimburses the cost of its production and makes a profit as the main source of expanded reproduction. For enterprises $\mathrm{A}$ and $\mathrm{B}$, this figure increases throughout the period from 2016 to 2018 .

Table 6. Turnover Ratios

\begin{tabular}{|l|c|c|c|c|c|c|}
\hline \multirow{2}{*}{ Indicators } & \multicolumn{3}{|c|}{ The enterprise A } & \multicolumn{3}{c|}{ The enterprise B } \\
\cline { 2 - 7 } & 2016 & 2017 & 2018 & 2016 & 2017 & 2018 \\
\hline $\begin{array}{l}\text { Finished goods } \\
\text { turnover }\end{array}$ & - & 1.4 & 1.3 & 1.2 & 1.5 & 0.72 \\
\hline $\begin{array}{l}\text { Inventory } \\
\text { turnover ratio }\end{array}$ & 2.9 & 1.9 & 1.8 & 1.3 & 2.2 & 1.3 \\
\hline $\begin{array}{l}\text { Turnover ratio of } \\
\text { current assets }\end{array}$ & 2.6 & 2.5 & 1.9 & 0.7 & 2.5 & 1.2 \\
\hline
\end{tabular}

Source: compiled by the authors on the basis of materials [9]

From the table 6 we can see, that the enterprise A is characterized by a decrease in finished goods turnover, inventory turnover ratio, turnover ratio of current assets during 2016-2018, and for the enterprise B this decrease is typical at the end of the period.

Finished goods turnover shows the turnover rate of outgoing inventory. An increase in the ratio means an increase in demand for the enterprise's products, and a decrease in the overstocking of outgoing inventory due to a decrease in demand (observed for the enterprise $A$ and and the enterprise $B$ at the end of study period).

The inventory turnover ratio shows the number of inventory turnovers. A decrease in this indicator means a relative increase in inventories, which negatively affects the enterprise financial condition(enterprise A in 2017-2018; enterprise B in 2018). The turnover ratio of current assets shows how many currency units a unit of current assets brings (for the enterprise $\mathrm{A}$ it decreased throughout the period, for the enterprise $\mathrm{B}$ at the end of the period).

Table 7. Financial Independence

\begin{tabular}{|l|c|c|c|c|c|c|}
\hline \multirow{2}{*}{ Indicators } & \multicolumn{3}{|c|}{ The enterprise A } & \multicolumn{3}{c|}{ The enterprise B } \\
\cline { 2 - 7 } & 2016 & 2017 & 2018 & 2016 & 2017 & 2018 \\
\hline $\begin{array}{l}\text { Financial } \\
\text { independence }\end{array}$ & 0.84 & 0.82 & 0.79 & 0.66 & 0.83 & 0.41 \\
\hline
\end{tabular}

Source: compiled by the authors on the basis of materials [9] 
Financial independence ratio (equity-assets ratio, ownership ratio, equity ratio) characterises equity integration. An increase in the financial sovereignty ratio means increasing the enterprise financial stability and is a positive moment. For the enterprises $\mathrm{A}$ and $\mathrm{B}$, the value of this ratio fluctuates between 0.4 and 0.84 , which is certainly not evidence of their financial stability, but only indicates the limited availability and inaccessibility of external financing.

\section{Conclusions}

The article analyses the activities of two agricultural enterprises and provides the assessement of possibilities for their further development. On the basis of study results of these enterprises, it is found out that during the two years they were characterized by a decrease in the average number of employees or its maintaining, an increase in the net income from the output realization, but that the enterprises received a loss, which is explained by the unstable economic situation and the increase in unit costs. For further successful development, the enterprises should take into account the factors that have contributed to this, develop a tree of goals and decisions, in order to keep management records to identify unprofitable activities.

\begin{abstract}
Entry: The need for a systematic analysis of the agricultural enterprises activities, monitoring their business activity due to unpredictable changes in their current activity and the need to evaluate the competitive environment. Such analysis allows to move to the crisis in a timely manner, to diagnose the enterprise potential, oriented on the analysis results of other enterprises activities. Therefore, the analytical review of agricultural activities of a number of Ukrainian enterprises for the period from 2016 to 2018 is relevant in terms of obtaining general information about the enterprises financial condition and their ability to survive and develop during the period is extremely difficult for the country. The aim of the article is to present the results of the analytical survey of the agricultural enterprises of Ukraine for the period from 2016 to 2018, to assess their opportunities for further development. The analysis of these enterprises activities, namely: horizontal and vertical analysis of the balance, increment rate calculation, profitability rario, turnover ratio, financial independence, dynamics of accounts receivable and inventories for the period from two thousand fourteen to two thousand sixteen is presented. Based on the calculations, an assessment is made of the possibilities for their further development.

Discussion: A survey of these services enterprises has revealed that over the three years they were characterized by a decrease or savings in the average number of employees, an increase in net income from output realization, but the enterprises received losses due to the unstable economic situation and an increase in unit costs. For the further successful development of enterprises, the factors that contribute to this should be taken into account, the tree of goals and decisions should be developed, and management records should be kept in order to identify unprofitable activities.
\end{abstract}

\title{
Список літератури:
}

1. Азарова А.О. Математичні методи та моделі оцінювання фінансового стану підприємства: монографія / А.О. Азарова, О.В. Рузакова. - В.: ВНТУ, 2010. - 172 с.

2. Волощук Л.А. Финансовый анализ / Л.А. Волощук, М.А. Юдин. - К.: «Освіта України», 2012. $328 \mathrm{c}$.

3. Безбородова Т.В. Сутність та необхідність аналізу фінансового стану / Т.В. Безбородова // Економіка. Управління. Інновації. - 2014. - Вип. 1 (11). - [Електронний ресурс]. - Режим доступу: http://irbis-nbuv.gov.ua/cgi-bin/irbis_nbuv/cgiirbis_64.exe?C21COM=2\&I21DBN=UJRN\& P21DBN=UJRN\&IMAGE_FILE_DOWNLOAD=1\&Image_file_name=PDF/eui_2014_1_9.pdf.

4. Коломієць Н.О. Методологічні аспекти оцінки фінансового стану як основи ефективного управління підприємством / Н.О. Коломієць, В.М. Павліченко, О.П. Коломієць // Вісник Харківського національного технічного університету сільського господарства імені Петра Василенка. - 2017. - № 185. - С. 223-230.

5. КрамаренкоГ.О. Фінансовий менеджмент / Г.О. Крамаренко, О.С. Чорна. - Київ: Центр учбової літератури, 2016. - 518 с.

6. Савицкая Г.В.Анализ хозяйственной деятельности предприятия / Г.В. Савицкая. - М.: ИНФРАM, 2018. $-378 \mathrm{c}$.

7. Томілін О.О. Сутність та оцінка фінансового стану сільськогосподарського підприємства / О.О. Томілін, А.С. Лесюк [Електронний ресурс]. - Режим доступу: http://globalnational.in.ua/archive/14-2016/115.pdf.

8. Білик В.Г. Облік і відображення в звітності фінансових результатів діяльності сільськогосподарських підприємств в умовах реформування / В. Г. Білик // Формування ринкових відносин в Україні. - К. : Науково-дослідний економічний інститут, 2014. - Вип. 1. C. 127-129. 
9. Державнва служба статистики України [Електронний ресурс]. - Режим доступу: http://www.ukrstat.gov.ua.SMIDA [Електронний ресурс]. - Режим доступу: https://smida.gov.ua.

10. Стратегічні напрями розвитку сільського господарства України на період до 2020 року. URL: http://agroua.net/docs/ strateg.pdf.

11. Бурачек I. В., Михайленко Н. В. Сучасний стан та перспективні напрями розвитку сільського господарства в Україні. Глобальні та національні проблеми економіки. 2018. № 21. С. 134-137.

12. Лупенко Ю. О., Месель-Веселяка В. Я. Стратегічні напрями розвитку сільського господарства України на період до 2020 року. К. :ННЦ IAE, 2012. 182 с.

\section{References:}

1. Azarov A. A. Mathematical methods and models for assessing the financial condition of the enterprise: monograph / A. A. Azarov, A. V. Ruzakova. - V.: VNTU, 2010. - 172 p.

2. Voloshchuk L. A. Financial analysis / L. A. Voloshchuk, N. And. Judah. - K.: "Education Of Ukraine", 2012. -328 p.

3. Bezborodova T. V. the Essence and necessity of financial analysis / T. V. Bezborodova // Economics. Control. Innovation. - 2014. - Vol. 1 (11). - [Electronic resource]. - Mode of access: http://irbisnbuv.gov.ua/cgi-bin/irbis_nbuv/cgiirbis_64.exe?C21COM=2\&I21DBN=UJRN\&

P21DBN=UJRN\&IMAGE_FILE_DOWNLOAD=1\&Image_file_name=PDF/eui_2014_1_9.pdf.

4. Kolomiets N. And. Methodological aspects of assessing the financial condition as a basis for effective management of the enterprise / N. And. Kolomiets, M. V., Pavlichenko, A. P. Kolomiets // Bulletin of Kharkov national technical University of agriculture named Peter Vasilenko. - 2017. - No. 185. - S. 223 to 230 were.

5. Kramarenko.And. Financial management / C. A. Kramarenko, A. Is. Black. - Kyiv: Center of educational literature, 2016. $-518 \mathrm{p}$.

6. Savitskaya GV Analysis of economic activity of the enterprise / H V. Savitskaya. - M.: INFRA - M, 2018. -378 p.

7. Tomilin A. A. the Nature and assessment of financial state of agricultural enterprises / A. A. Tomilin, S. A. lesyuk [Electronic resource]. - Mode of access: http://global-national.in.ua/archive/14-2016/115.pdf

8. Bilyk V. G. Accounting and reporting of financial results of agricultural enterprises in conditions of reforming / U. G. Bilyk // Formation of market relations in Ukraine. - K. : Scientific-research economic Institute, 2014. - Vol. 1. - S. 127-129.

9. Derzhavna statistics service of Ukraine [Electronic resource]. - Mode of access: http://www.ukrstat.gov.ua.SMIDA [Electronic resource]. - Mode of access: https://smida.gov.ua.

10. Strategic directions of development of agriculture of Ukraine for the period until 2020. URL: http://agroua.net/docs/ strateg.pdf.

11. Burachek V. I., Mikhailenko N. V. Modern condition and perspective directions of development of agriculture in Ukraine. Global and national problems of Economics. 2018. No. 21. P. 134-137.

12. Lupenko Y. A., Masel of Veselka V. Y. the Strategic directions of development of agriculture of Ukraine for the period until 2020. K. :NNTS IAE, 2012. 182 p.

\section{Посилання на статтю:}

Balan A.A. Business activity of enterprises: analytical review / A.A. Balan, V.S. Timonyuk // Economics: time realities. Scientific journal. - 2020. - № 1 (47). - P. 12-19. - Retrieved from https://economics.opu.ua/files/archive/2020/No1/12.pdf.

DOI: 10.15276/ETR.01.2020.2. DOI: 10.5281/zenodo.3967274.

\section{Reference a Journal Article:}

Balan A.A. Business activity of enterprises: analytical review / A.A. Balan, V.S. Timonyuk // Economics: time realities. Scientific journal. - 2020. - № 1 (47). - P.12-19. - Retrieved from https://economics.opu.ua/files/archive/2020/No1/12.pdf.

DOI: 10.15276/ETR.01.2020.2. DOI: 10.5281/zenodo.3967274. 